\title{
New fossil records of Xyelidae (Hymenoptera) from the Middle Jurassic of Inner Mongolia, China
}

\author{
Yan $\mathrm{ZHENG}^{1, *}$, Haiyan $\mathrm{HU}^{2}$, Dong $\mathrm{CHEN}^{3}$, Jun $\mathrm{CHEN}^{4}$, \\ Haichun $\mathrm{ZHANG}^{5}$ \& Alexandr P. RASNITSYN ${ }^{6, *}$ \\ ${ }^{1,4}$ Institute of Geology and Paleontology, Linyi University, Shuangling Rd., Linyi 276000, China. \\ ${ }^{1,4,5}$ State Key Laboratory of Palaeobiology and Stratigraphy, Nanjing Institute of Geology \\ and Palaeontology, East Beijing Road, Nanjing 210008, China. \\ ${ }^{2}$ School of Agronomy and Environment, Weifang University of Science and Techonoly, \\ Jinguang Road, Shouguang, 262700, China. \\ ${ }^{3}$ School of Environmental and Municipal Engineering, Qingdao University of Technology, \\ Qingdao 266033, China. \\ ${ }^{6}$ Palaeontological Institute, Russian Academy of Sciences, Moscow, 117647, Russia. \\ ${ }^{6}$ Natural History Museum, London SW7 5BD, UK. \\ *Corresponding authors: zhengyan536@163.com, alex.rasnitsyn@gmail.com \\ 2Email: huhaiyanzy@163.com \\ ${ }^{3}$ Email: chendong_cau@163.com \\ Email: rubiscada@sina.com \\ 55mail: hczhang@nigpas.ac.cn \\ ${ }^{1}$ urn:1sid:zoobank.org:author:28EB8D72-5909-4435-B0F2-0A48A5174CF9 \\ 2 urn:lsid:zoobank.org:author:91B2FB61-31A9-449B-A949-7AE9EFD69F56 \\ ${ }^{3}$ urn:lsid:zoobank.org:author:51D01636-EB69-4100-B5F6-329235EB5C52 \\ ${ }^{4}$ urn:Isid:zoobank.org:author:8BAB244F-8248-45C6-B31E-6B9F48962055 \\ ${ }^{5}$ urn:1sid:zoobank.org:author:18A0B9F9-537A-46EF-B745-3942F6A5AB58 \\ ${ }^{6}$ urn:1sid:zoobank.org:author:E7277CAB-3892-49D4-8A5D-647B4A342C13
}

\begin{abstract}
A new genus and two new species of Xyelidae Newman, 1834 (Hymenoptera Linnaeus, 1758), Platyxyela tenuis sp. nov. and Scleroxyela daohugouensis gen. et sp. nov. are described and illustrated from the Middle Jurassic Daohugou Beds of Ningcheng, Inner Mongolia, China. Platyxyela tenuis sp. nov. (Xyelinae Newman, 1834, Liadoxyelini Rasnitsyn, 1966) can be distinguished from its congeners by short forewing length and ovipositor sheath strongly narrowed toward acute apex. Scleroxyela daohugouensis gen. et sp. nov. is placed within Macroxyelinae Ashmead, 1898, Xyeleciini Benson, 1945 based on pterositigma completely sclerotised and costal space sclerotised before ptrostigma, 1-Rs half as long as 1-M, and 1m-cu short. It is the first recorded species of Xyeleciini in Daohugou Beds. Furthermore, an updated key of identification of subfamilies and tribes of Xyelidae is provided. Our findings of new morphological data provide insights into the early evolution of Hymenoptera, as well as effectively enrich our understanding of the diversity of Xyelidae in the Mesozoic.
\end{abstract}

Keywords. Mesozoic, fossil insects, Daohugou, taxonomy, new taxon. 
Zheng Y., Hu H., Chen D., Chen J., Zhang H. \& Rasnitsyn A.P. 2021. New fossil records of Xyelidae (Hymenoptera) from the Middle Jurassic of Inner Mongolia, China. European Journal of Taxonomy 733: 146-159. https://doi.org/10.5852/ejt.2021.733.1229

\section{Introduction}

The small extant group of distinctive sawflies, Xyelidae Newman, 1834, has been considered to be the most primitive of Hymenoptera Linnaeus, 1758 (Rasnitsyn 1980; Zhang \& Zhang 2000), and plays a vital role as an ancestral group in the early evolution of hymenopterans. This family has been reported as the earliest appearance on the hymenopteran cladogram from the Middle or Upper Triassic of Kyrgyzstan (Rasnitsyn 1964, 1969, 1980), and the Upper Triassic of Australia (Riek 1955; Engel 2005), South Africa (Schlüter 2000) and Argentina (Lara et al. 2014). The diversity of this family in the Mesozoic was much broader than today. Hitherto, more than 80 species within 47 genera attributed to Xyelidae have been reported from the Mesozoic (Rasnitsyn 1964, 1969, 1977,1980; Zhang \& Zhang 2000; Wang et al. 2012; Kopylov 2014; Zheng et al. 2019). In contrast, the incomparably better studied extant fauna of the family embraces 75 described species in 5 genera (Taeger et al. 2010; corrected for Xyela Dalman, 1819 according to Blank et al. 2013). Aguiar et al. (2013) provided still more impressive figures, 5 living genera and 63 species vs 47 extinct genera and 93 species. Yet, the past xyelid diversity is strongly underexplored as lots of undescribed fossils are known to be waiting for their explorer already stored in the collections with which the authors dealt now or dealt before. The present publication makes a small input to that end describing one new genus and two new species of Xyelidae from the famous midJurassic Lagerstätte Daohugou in Northeastern China.

The Daohugou area is one of the most important insect fields containing abundant, diverse, and excellently preserved fossils (Rasnitsyn \& Zhang 2004, 2010; Zhang 2012; Makarkin et al. 2013; Liu et al. 2014; Wang et al. 2016; Zheng et al. 2016; Zheng \& Chen 2017). This holds true for the sawfly family Xyelidae, accounting for almost $15 \%$ of Hymenoptera in the Daohugou collection kept at the Nanjing Institute of Geology and Palaeontology, which early in the $21^{\text {st }}$ century displayed at least two subfamilies and three tribes of Xyelidae (Rasnitsyn \& Zhang 2004). We herein report the discovery of one new genus and two new species, Platyxyela tenuis sp. nov., and Scleroxyela daohugouensis gen. et sp. nov. based on two well-preserved xyelid specimens from the Middle Jurassic Daohugou Beds of

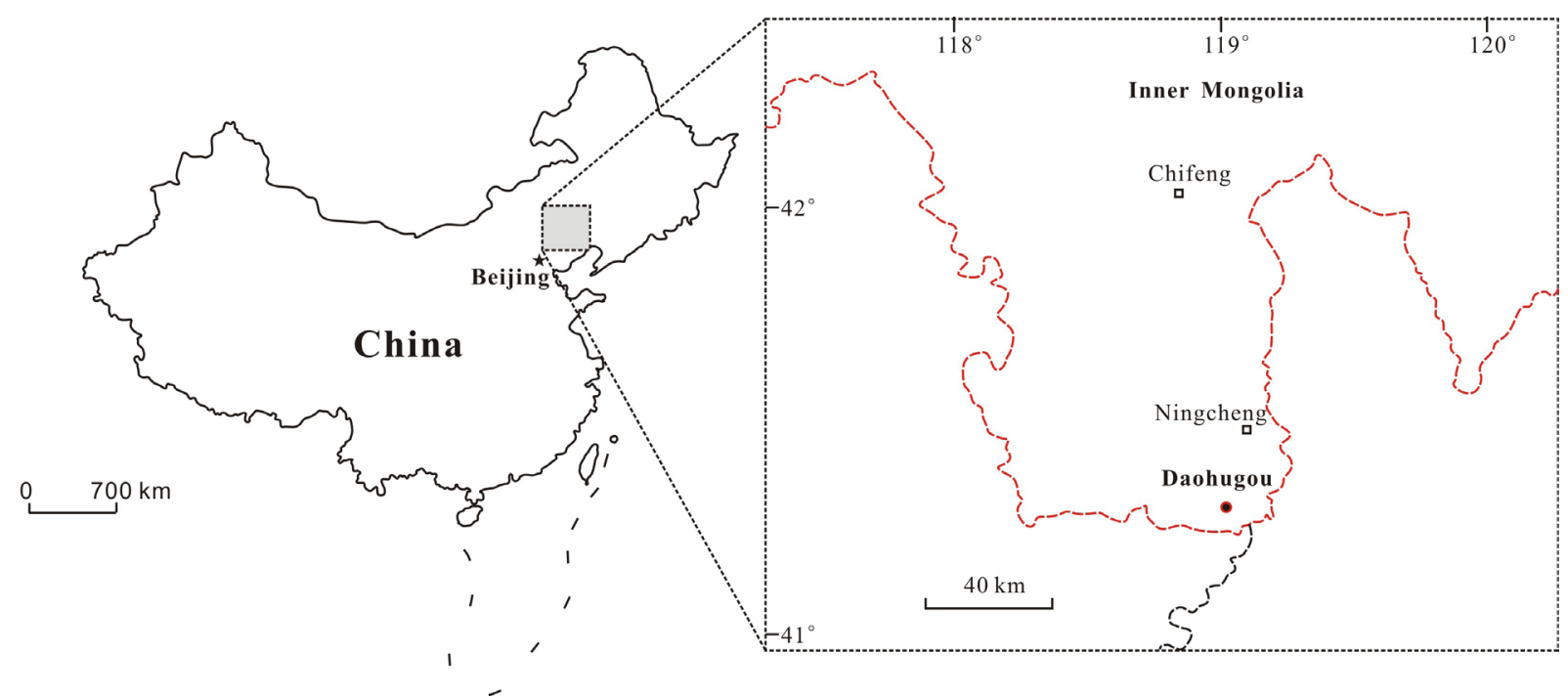

Fig. 1. Geographical sketch map showing the insect fossil locality in Daohugou area, Ningcheng City, Inner Mongolia, China. 
Ningcheng, Inner Mongolia, China. The key to identification of subfamilies and tribes of Xyelidae is also updated and provided. Our findings present some new remarks on the early evolutionary history of the Xyelidae, and also expand the knowledge of the diversity of this family in the Mesozoic.

\section{Material and methods}

The fossil specimens studied were collected from Daohugou Village (41 ${ }^{\circ} 38^{\prime \prime}$ N; $119^{\circ} 8^{\prime} 38^{\prime \prime}$ E), Shantou Township, Ningcheng City, Inner Mongolia, China (Fig. 1) and are deposited in the Nanjing Institute of Geology and Palaeontology, Chinese Academy of Sciences (NIGP, CAS). The locality is dated as the latest Middle Jurassic, Jiulongshan Formation (Chen et al. 2004).

The fossils were examined and photographed by standard paleoentomological methods, using the VHX 5000 digital microscope platform. Line drawings were done with CorelDRAW ver. 14.0 and Adobe Photoshop CS6. The measurements of specimens were made using NIH ImageJ software (http://rsb.info.nih.gov/ij/). The wing venation terminology used is basically adapted from Huber \& Sharkey (1993).

\section{Results}

Order Hymenoptera Linnaeus, 1758

Suborder Symphyta Gerstaecker, 1867

Superfamily Xyeloidea Newman, 1834

Family Xyelidae Newman, 1834

\section{Remarks}

The system of Xyelidae considering its present and past diversity was developed a half century ago (Rasnitsyn 1966, 1969) and badly needs reconsideration now because the description of numerous new genera has made the diagnostic of tribes and subfamilies rather tricky and results in many mistakes. However this is a subject of a special work which is hardly possible to perform in the near future. In the meantime, to help current researches in the field of past diversity of the family, we have constructed an updated, although preliminary, key to the identification of the subfamilies and tribes of Xyelidae particularly addressed to fossil material.

\section{Key to subfamilies and tribes of Xyelidae}

1. Along $\mathrm{R}$, cell $2 \mathrm{r}$ longer than, or as long as, or very rarely slightly shorter than, $1 \mathrm{r}$. Triassic ............ 2

- Along R, cell $2 \mathrm{r}$ shorter than or, very rarely, as long as 1r. J-R (Jurassic through Recent)............... 3

2. Rs two-branched (cell $4 \mathrm{r}$ present) Archexyelinae Rasnitsyn, 1964

- Rs simple (no 4r cell) Madygellinae Rasnitsyn, 1969

3. Costal space apical with no sclerotisation connecting $\mathrm{C}$ with $\mathrm{R}$. Pterostigma not sclerotised (dark) except sometimes basally. Ovipositor long, extending behind abdomen, never very wide. Xyelinae

- Costal space apical with vertical sclerotisation between $\mathrm{C}$ with $\mathrm{R}$ delimited from pterostigma with costal break (membranose slit permitting pterostigma with distal wing to turn up and down at flight), or that area widely desclerotised, expanding to both end of costal space and base of pterostigma (as in Ceroxyelini). Pterostigma sclerotised (dark) basally or throughout, sometimes except centrally. Ovipositor not narrow, extending far behind abdomen only when very wide. Macroxyelinae. 
4. 1-Rs longer than 1-M, 1m-cu longer than $0.6 \times 3-\mathrm{Cu}$. J-R Xyelini Newman, 1834

- 1-Rs shorter than 1-M, 1m-cu at most $0.6 \times$ as long as 3-Cu. Jurassic and Early Cretaceous Liadoxyelini Rasnitsyn, 1966

5. Sc hind branch entering $\mathrm{R}$ distal of Rs base 6

- Sc hind branch entering $\mathrm{R}$ basal or at Rs base

6. 1-Rs shorter than 1-M. Area around costal break widely desclerotised. $1^{\text {st }}$ flagellomere much shorter than posterior flagellomeres together. Early Cretaceous Ceroxyelini Rasnitsyn, 1969

- 1-Rs not distinctly shorter than 1-M. Area around costal break narrowly or not at all desclerotised. $1^{\text {st }}$ flagellomere not shorter than posterior flagellomeres together. J-R

Macroxyelini Ashmead, 1898

7. 1-Rs half as long as 1-M or shorter. Pterostigma sclerotised throughout or except centrally, usually with distinct desclerotisation around costal break. J-R Xyeleciini Benson, 1945

- 1-Rs distinctly longer than half 1-M. Pterostigma rarely with distinct desclerotisation around costal break. Jurassic and Early Cretaceous.

8. Pterostigma sclerotised basally....................................................... Angaridyelini Rasnitsyn, 1966

- Pterostigma sclerotised throughout (sometimes except centrally) ....Gigantoxyelini Rasnitsyn, 1969

Subfamily Xyelinae Newman, 1834

Tribe Liadoxyelini Rasnitsyn, 1966

\section{Type genus}

Liadoxyela Martynov, 1937.

\section{Remarks}

This tribe was proposed for four genera (Liadoxyela Martynov, 1937, Kirghizoxyela Rasnitsyn, 1966, Anomoxyela Rasnitsyn, 1966, and Lydoxyela Rasnitsyn, 1966) and five species from Jurassic and Early Cretaceous of Siberia and Central Asia, based on a set of diagnostic characters including short $1 \mathrm{~m}-\mathrm{cu}$ (about half as long as 3-Cu) as distinguishing it from Xyelini Newman, 1834, the only other tribe in subfamily Xyelinae (Rasnitsyn 1966). The next revision of Xyelidae and Symphyta in general (Rasnitsyn 1969) added another diagnostic feature, 1-Rs not longer than 1-M. One more genus (Orthoxyela Rasnitsyn, 1983) and two species from the Jurassic of Siberia have been added to the tribe since (Rasnitsyn 1983). Much later three further genera (Platyxyela Wang et al., 2012, Cathayxyela Wang et al., 2014, Aequixyela Wang et al., 2014), each with one species from the Middle Jurassic of China, have been added to the tribe, even though not without confusion (Wang et al. 2012, 2014). The first genus was described in Macroxyelinae Ashmead, 1898 but later listed under Liadoxyelini Rasnitsyn, 1966 (Wang et al. 2014: table 1). Judging from their descriptions and the table 1, Cathayxyela and Aequixyela were equally described as members of Liadoxyelini, but this was under the title Xyelini which we consider a lapsus calami. We agree with the interpretation of Platyxyela and Cathayxyela as members of Liadoxyelini. However, Aequixyela differs from other Liadoxyelini considerably in having 1-Rs scarcely longer than 1-M, 1m-cu distinctly longer than half 3-Cu, pterostigma distinctly inflated (often in Xyelini but never in Liadoxyelini), and unlike all Xyelidae, ovipositor very short and narrow. Unusual is also the very short antennal flagellum, only comparable with that in living Macroxyelini Ashmead, 1898. The position of the latter genus needs special consideration: for the moment we consider it as Xyelinae incertae tribus. 
Type species

Genus Platyxyela Wang et al., 2012

Platyxyela unica Wang et al., 2012.

Platyxyela tenuis sp. nov.

urn:1sid:zoobank.org:act:62A596B3-6015-4A3F-A55D-694B33EDC5B7

Figs $2-3$

\section{Diagnosis}

Forewing long (7.9 $\mathrm{mm}$ in length), ovipositor sheath as long as $\mathrm{M}+\mathrm{Cu}$ and strongly narrowed toward acute apex.

\section{Etymology}

The specific name tenuis, thin, feminine gender of the Latin, referring to the thinness and delicateness of the body.

\section{Type material}

Holotype, female, NND0176 with well-preserved body, wings complete but legs incomplete; NIGP.

\section{Locality and horizon}

Daohugou Village, Wuhua Township, Ningcheng County, Chifeng City, Inner Mongolia, China, Jiulongshan Formation, Middle Jurassic (Callovian-Bathonian boundary).

\section{Comparison}

Platyxyela tenuis sp. nov. is without pterostigma sclerotised completely, 1-Rs obviously shorter than $1-\mathrm{M}$ and $1 \mathrm{~m}$-cu half as long as $3-\mathrm{Cu}$, which indicate the position of the new species in Xyelinae, Liadoxyelini. This new species differs from $P$. unica in forewing length $(7.9 \mathrm{~mm}$ vs $12.3-16.5 \mathrm{~mm}$ in $P$. unica), ovipositor sheath length and shape (ovipositor sheath relatively much longer and slowly narrowing to rounded apex in $P$. unica).

\section{Description}

Female sawfly in ventral view with approximately complete wings and full body. Head large and nearly round; eyes somewhat infuscated; antenna ca 2.7 times as long as width of head, scape about three times as long as pedicel, pedicel short, 0.11 times as long as $1^{\text {st }}$ flagellomere, the latter thickened and elongated, but obviously shorter than flagellum; flagellum with at least eight segments, each longer than wide.

Thorax slightly wider than head. Propleura large, mesonotum with notauli distinct and complete, medial mesoscutal line long and thin, mesoscutellum strongly elevated. Mesopleuron smooth, without discernible wrinkles.

Forewing with pterostigma sclerotised basally only; pterostigma narrow and nearly half as wide as cell 2r; costal area obviously dilated proximad of base of Rs; Sc with two branches, Sc1 merging with C beyond origin of Rs, Sc2 short and almost vertical, meeting R before origin of Rs; Sc2 nearly equal to 1-Rs and the latter distinctly shorter than 1-M; 3-M about 3 times as long as 2-M; R strongly curved before origin of Rs and slightly thickened before pterostigma; cross vein 1r-rs subparallel to 2r-rs and 0.8 times as long as it; base of 2r-rs 0.7 times as distant from apex of pterostigma as from base of 1r-rs; Rs $+\mathrm{M}$ at least six times as long as 1-Rs; section of Rs between 1r-rs and 2r-rs arched toward lower 
margin of forewing, end of Rs1 closer to pterostigma than to Rs2; $\mathrm{M}+\mathrm{Cu}$ sinuate; $1 \mathrm{~m}-\mathrm{cu} 0.7$ times as long as $2-\mathrm{Cu}$ and half as long as $3-\mathrm{Cu} ; 2 \mathrm{~m}-\mathrm{cu}$ inclined towards wing base and half as long as $4-\mathrm{Cu}$; length proportions of cells $1 \mathrm{r}: 2 \mathrm{r}: 3 \mathrm{R}: 4 \mathrm{r}: 1 \mathrm{mcu}: 2 \mathrm{mcu}=1.8: 0.9: 1.2: 1.9: 1.7: 2.1$.

Hindwing with 1r-m long, meeting Rs it is very base; 1-M ca 0.3 times as long as $1 \mathrm{r}-\mathrm{m}$; m-cu not reaching 3r-m for about half of its ( $\mathrm{m}-\mathrm{cu}$ ) length; cell $1 \mathrm{cu}$ long and widened at origin of M; cu-a arcuate basally; cell 1a slightly shorter than cell cua; $\mathrm{M}$ and $\mathrm{Cu}$ with free ends not reaching wing margin, $1 \mathrm{~A}$ with no free end; $3 \mathrm{~A}$ almost as long as $\mathrm{M}+\mathrm{Cu}$.

Foreleg thin and short. Midleg femur ca 4.8 times as long as wide, tibia slightly shorter than femur, tarsus with basitarsus as long as three following segments combined; first segment elongated and fourth segment shortest. Hindleg longer and wider than midleg, coxa long, femur ca 5.3 times as long as wide, tibia 1.25 times as long as femur and nearly $2 / 3$ as wide as femur, tarsus with four preserved segments, apparently similar to mid one in proportions.

Abdomen with nine visible segments; ovipositor sword-shaped, with sheath twice as long as valvifer II.

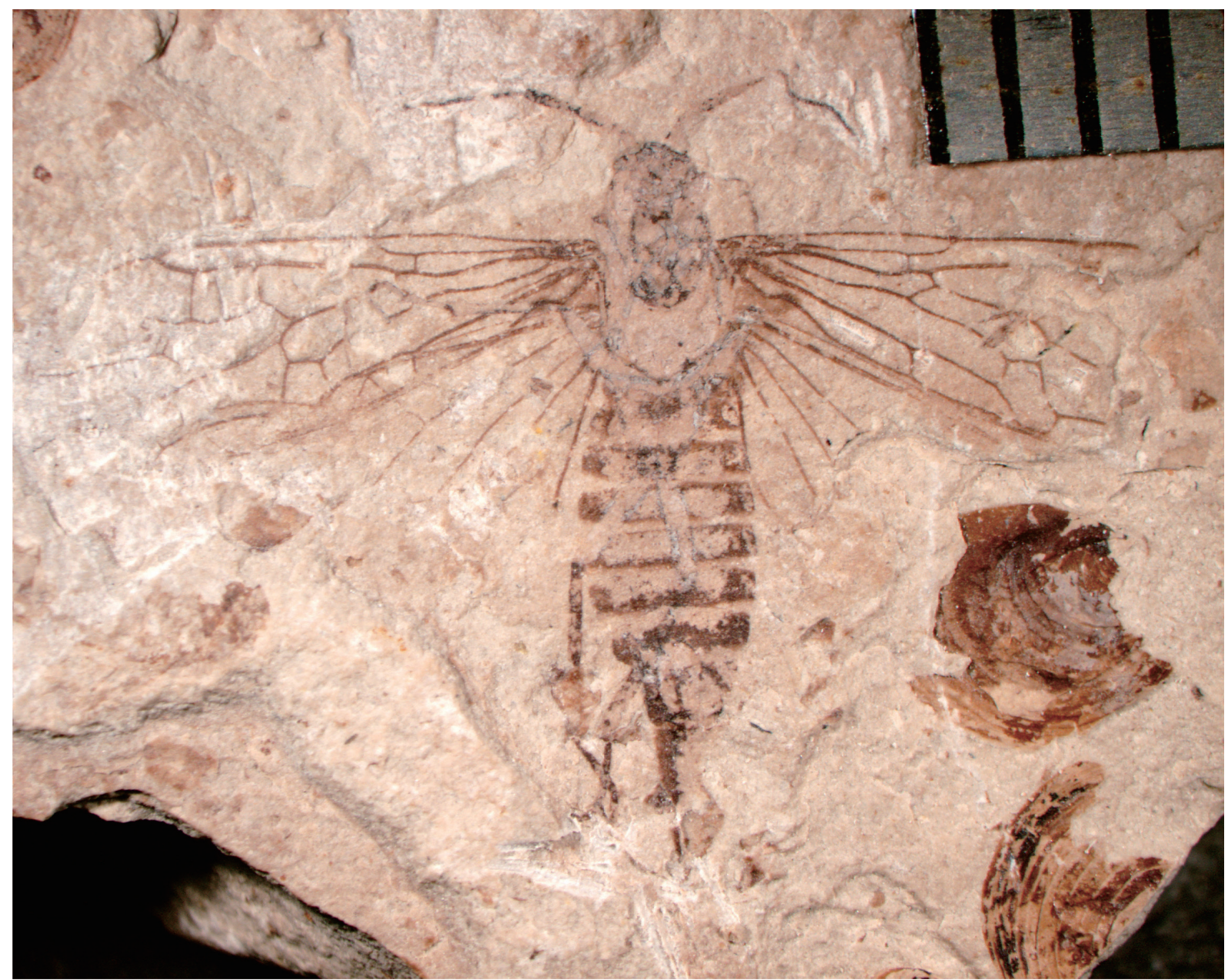

Fig. 2. Photograph of Platyxyela tenuis sp. nov. Holotype, NND0176. Ruler unit (top right): $1 \mathrm{~mm}$. 


\section{Measurements}

Body length (excluding ovipositor sheath) $7.8 \mathrm{~mm}$ long. Head width $1.2 \mathrm{~mm}$, length $1.1 \mathrm{~mm}$. Antennae not shorter than $3.2 \mathrm{~mm}$, third antennal article ca $1.5 \mathrm{~mm}$. Length of forewing ca $7.9 \mathrm{~mm}$; maximum width of forewing ca $2.9 \mathrm{~mm}$. Thorax $1.8 \mathrm{~mm}$ in length and abdomen $5.1 \mathrm{~mm}$ in length. Length of ovipositor $3.6 \mathrm{~mm}$, with valvifer II $1.2 \mathrm{~mm}$ and ovipositor sheath $2.3 \mathrm{~mm}$.
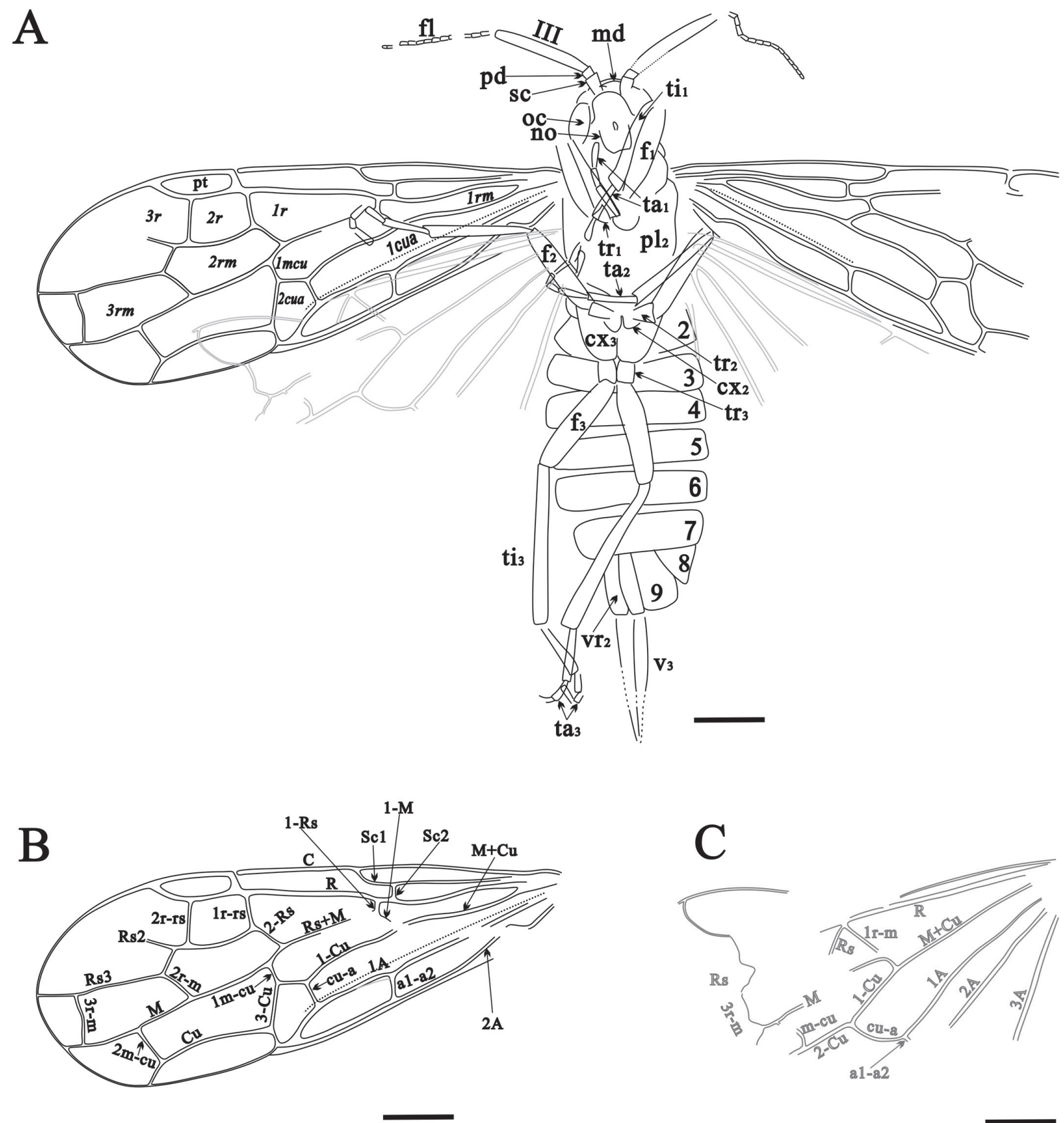

Fig. 3. Line drawings of Platyxyela tenuis sp. nov. A. Habitus, holotype. B. Left forewing. C. Left hindwing. Symbols: $\mathrm{cx}_{2}, \mathrm{cx}_{3}=$ mid and hind coxae; $\mathrm{f}_{1}, \mathrm{f}_{2}, \mathrm{f}_{3}=$ fore, mid and hind femur; $\mathrm{fl}=$ flagellum; $\mathrm{md}=$ mandible; $\mathrm{no}=$ notaulus; $\mathrm{oc}=$ eye; $\mathrm{pd}=$ pedicel; $\mathrm{pl}_{2}=$ mesopleuron; $\mathrm{sc}=\mathrm{scape} ; \mathrm{ta}_{1}, \mathrm{ta}_{2}, \mathrm{ta}_{3}=$ fore, mid and hind tarsus; $\mathrm{ti}_{1}, \mathrm{ti}_{3}=$ fore and hind tibia; $\mathrm{tr}_{1}, \mathrm{tr}_{2}, \mathrm{tr}_{3}=$ fore, mid and hind trochanter; $\mathrm{v}_{3}$ $=$ ovipositor sheath; $\mathrm{vr}_{2}=$ second valvifer; $1-9=$ abdominal segments; III $=$ enlarged third antennal segment; venational symbols standard, names of wing cells italicised. Scale bars: $1 \mathrm{~mm}$. 


\author{
Subfamily Macroxyelinae Ashmead, 1898 \\ Tribe Xyeleciini Benson, 1945 \\ Genus Scleroxyela gen. nov. \\ urn:Isid:zoobank.org:act:BE50D27E-AD6E-4772-81EF-BEB1FC3B6B08
}

\title{
Type species
}

Scleroxyela daohugouensis gen et sp. nov.

\section{Etymology}

The generic name is a combination of the Latin prefix sclero, referring to the forewing with pterostigma completely sclerotised, and Xyela, the type genus of Xyelidae. The gender is feminine.

\section{Diagnosis}

Forewing with pterostigma completely sclerotised; costal area sclerotised apically; Sc two-branched, with posterior branch short, vertical, joining $\mathrm{R}$ for short distance before origin of Rs, and anterior branch long, surpassing Rs base; 1-Rs distinct, obviously shorter than 1-M; crossvein 1r-rs subvertical, shorter than 2r-rs; $1 \mathrm{~m}$-cu short, ca 0.4 times as long as $3-\mathrm{Cu}$; cell $1 \mathrm{mcu}$ long and narrow, 3.0 times as long as wide. Antenna with segment 3 distinctly longer than both head width and length of flagellum. Ovipositor sheaths longer than Rs + M.

\section{Composition}

Type species only.

\section{Remarks}

Scleroxyela gen. nov. is attributed to Macroxyelinae, based on the sclerotised pterostigma, and on the apex of the costal space before the pterostigma and the wide ovipositor sheaths, and to Xyeleciini Benson, 1945 based on the short 1-Rs and $1 \mathrm{~m}$-cu, and on the relatively long ovipositor sheaths (longer than in non-xyeleciine Macroxyelinae, even though shorter than in Xyelinae). It differs from the other xyeleciine genera by the absence of desclerotisation at the pterostigmal base, and also from Xyelites Rasnitsyn, 1966 and Uroxyela Rasnitsyn, 1966 in having a distinct 1-Rs and a long $3^{\text {rd }}$ antennal segment, from Microxyelecia Rasnitsyn, 1969 in having a long $3^{\text {rd }}$ antennal segment and a long fore Sc branch, and from Xyelecia Ross, 1932 in having a shorter flagellum, a longer ovipositor, and a long fore branch of Sc in the fore wing.

Scleroxyela daohugouensis gen. et sp. nov. urn:1sid:zoobank.org:act:D2420568-B709-4DF1-BCD7-B96E60034D5E

Figs 4-5

\section{Diagnosis}

As for genus.

\section{Etymology}

The specific name is derived from Daohugou village, where the type specimen was found.

\section{Type material}

Holotype, female, NND0185; NIGP. 


\section{Locality and horizon}

Daohugou Village, Wuhua Township, Ningcheng County, Chifeng City, Inner Mongolia, China: Jiulongshan Formation, Middle Jurassic (Callovian-Bathonian boundary).

\section{Description}

Female sawfly in ventral view with incomplete wings and body. Head large and subovate, with gena long and possibly postgenal bridge present, no eyes and ocelli visible in ventral view. Antenna ca 1.8 times as long as the width of head, scape with only apical part visible, obviously wider than pedicel, third segment approximately twice as thick as flagellum and distinctly longer than the latter.

Thorax obviously wider than head; propleurae smooth and relatively small, notauli well impressed, incompletely preserved, medial mesoscutal line long and deep; prosternum large, butterfly-like.

Forewing with pterostigma lanceolate and very narrow; costal area obviously widened proximad of base of Rs; Sc bifurcate, Sc1 connecting C beyond origin of Rs, Sc2 short and subvertical, meeting R before origin of Rs, $\mathrm{Sc} 1$ at least twice as long as $\mathrm{Sc} 2$; 1-Rs half as long as 1-M; crossvein 1r-rs subparallel to 2r-rs and 0.7 times as long as it; distance of 2r-rs to apex of pterostigma as long as distance from 2r-rs to 1r-rs; $\mathrm{M}+\mathrm{Cu}$ almost straight; $\mathrm{Rs}+\mathrm{M}$ approximately five times as long as 1-Rs; 3 -Rs arching; $1 \mathrm{~m}$-cu not

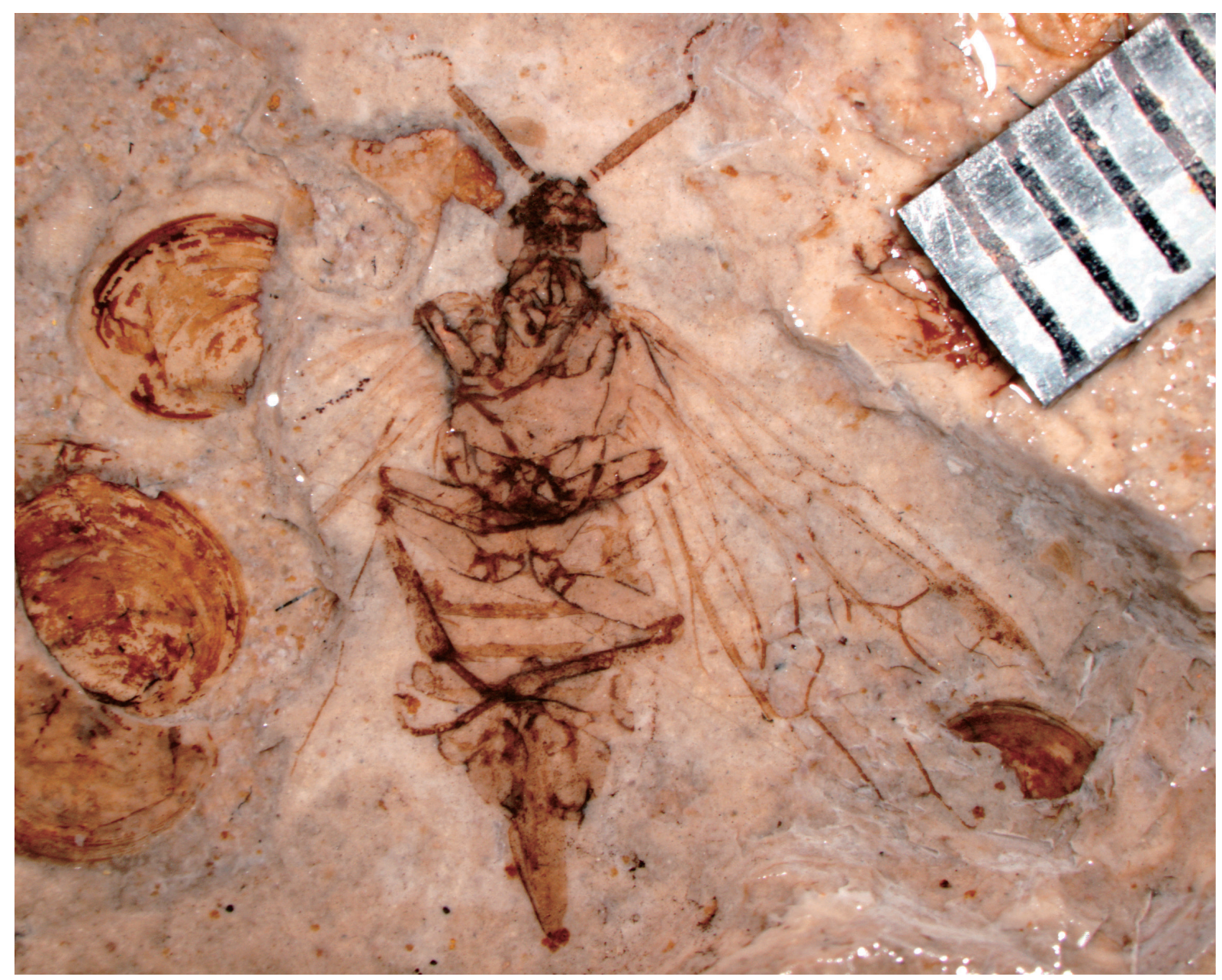

Fig. 4. Photograph of Scleroxyela daohugouensis gen. et sp. nov. Holotype, NND0185. Ruler unit (top right): $1 \mathrm{~mm}$. 
A

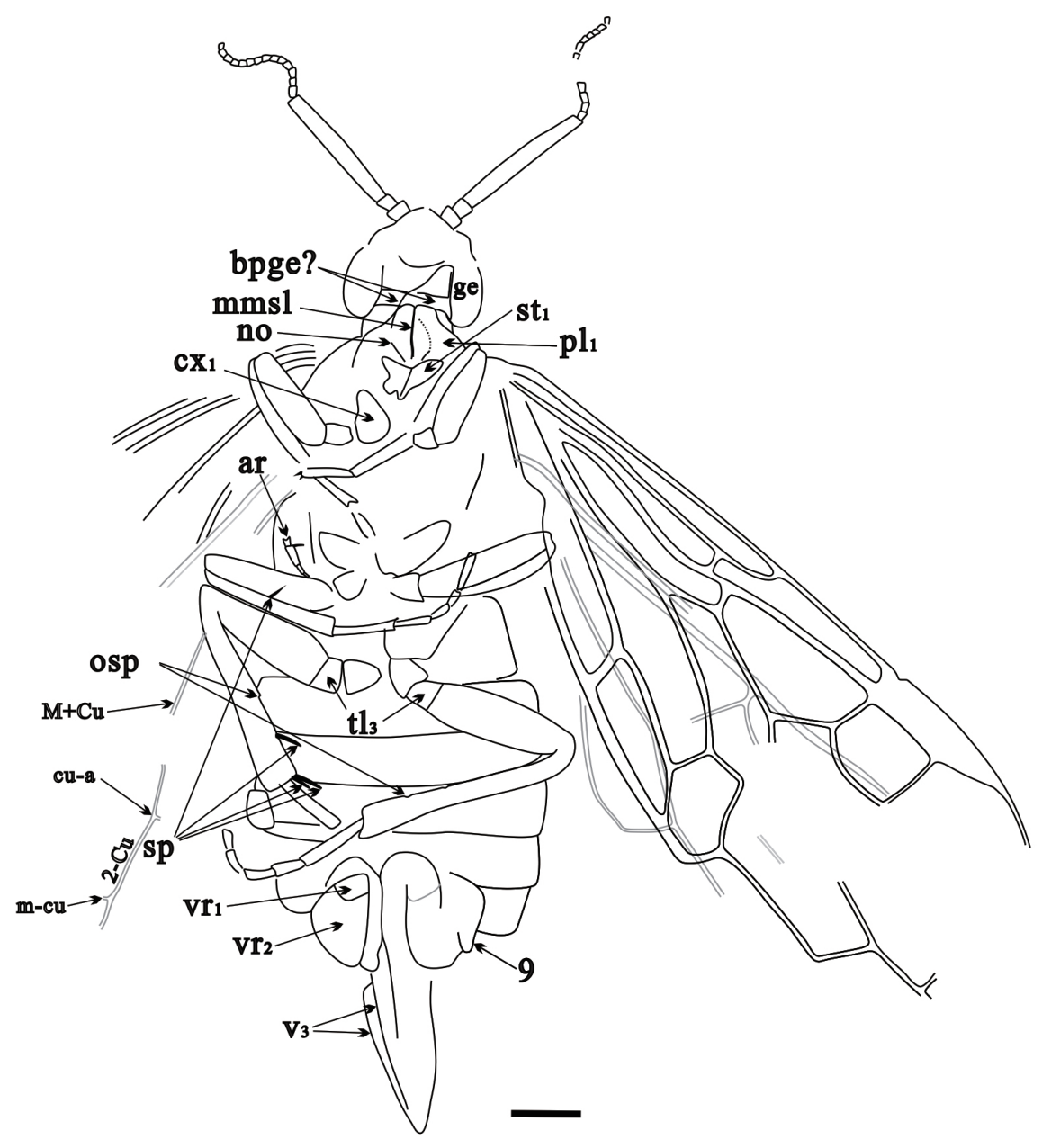

B

$\mathrm{C}$
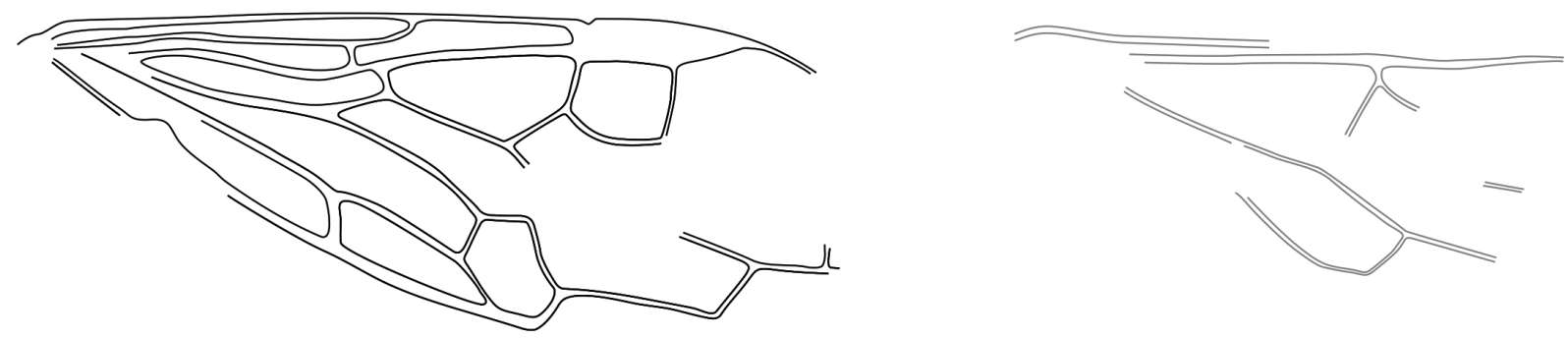

Fig. 5. Line drawings of Scleroxyela daohugouensis gen. et sp. nov. A. Habitus, holotype. B. Right forewing. C. Right hindwing. Symbols as in Fig. 3 except: ar = arolium; bpge? = possible postgenal bridge $; \mathrm{ge}=$ gena $; \mathrm{mmsl}=$ medial mesoscutal line; $\mathrm{osp}=$ attachment site of tibial spur; $\mathrm{pl}_{1}=$ propleuron; $\mathrm{sp}=$ tibial spur; $\mathrm{st}_{1}=$ prosternum; $\mathrm{tl}_{3}=$ hind trochantellus. Scale bars: $1 \mathrm{~mm}$. 
preserved but as restored about as long as $2-\mathrm{Cu}$ and half as long as $3-\mathrm{Cu} ; 2 \mathrm{~m}-\mathrm{cu}$ as long as $\mathrm{M}$ between it and $3 \mathrm{r}-\mathrm{m}$, inclined toward wing base; length proportion of cells $1 \mathrm{r}: 2 \mathrm{r}: 1 \mathrm{mcu}: 2 \mathrm{mcu}=2.5: 1.3: 2.7: 2.8$.

Hindwing partly preserved, with 1-Rs short but distinct, 1-Cu as long as 1-M and 1r-m combined, cu-a about half as long as 1-Cu and 2-Cu.

Foreleg short with coxa, trochanters, femora, tibiae and incomplete tarsi seen. Forecoxae trapezoidal, ca 0.7 times as long as wide, trochanter ca 1.4 times as long as wide, foretibia with two spurs visible, one long and one short. Midleg with coxa large and trapezoidal, trochanter small and rectangular, femur slightly thicker than fore femur, tibia with one preapical spur visible, tarsus complete, with basitarsus shorter than three following segments combined, fifth segment about as long as third and fourth segments together, claw small, arolium distinct. Hindleg with coxa large and trapezoidal, trochanter small, wider than long, trochantellus not much smaller than trochanter, femur longer and wider than in midleg, tibia ca 0.7 times as long as femur and half as long as femur in width, with one preapical spur and socket of another more basal one visible and with two short apical spurs, tarsus longer and wider than in midleg, with fifth segment short or, rather, incompletely preserved, others similar to mid tarsus.

Abdomen with seven visible segments, ovipositor well developed, with wide sword-shaped sheath, gradually tapering toward narrowly rounded apex, length ratio of valvifer 1 : valvifer 2 : valvula $3=$ $0.5: 1.6: 2.4$

\section{Measurements}

Body length excluding ovipositor sheath $11.5 \mathrm{~mm}$. Head width $2.1 \mathrm{~mm}$, length $1.5 \mathrm{~mm}$. Antennae not shorter than $4.3 \mathrm{~mm}$, third antennal article ca $2.1 \mathrm{~mm}$. Incomplete forewing length as preserved ca $11.1 \mathrm{~mm}$, maximum width ca $4.5 \mathrm{~mm}$. Length of thorax $3.6 \mathrm{~mm}$, abdomen $6.5 \mathrm{~mm}$. Ovipositor sheath length $2.2 \mathrm{~mm}$.

\section{Discussion}

Until now, five species of Xyelidae are described from the Middle Jurassic of Daohugou, including two of Macroxyelinae, Gigantoxyelini Rasnitsyn, 1969 (Abrotoxyela lepida Gao, Shih \& Ren, 2009 and A. multiciliata Gao, Shih \& Ren, 2009; Gao et al. 2009) and three in Xyelinae, Liadoxyelini (Cathayxyela extensa Wang, Rasnitsyn \& Ren, 2014, Platyxyela unica Wang, Shih \& Ren, 2012, and Aequixyela immensa Wang, Rasnitsyn \& Ren, 2014; Wang et al. 2014; attribution of Ae. immensa to Liadoxyelini leaves certain doubts, see above). The present publication adds one new species to the genus Platyxyela already known there and one new genus and species representing a tribe, Xyeleciini, reported at Daohugou for the first time. As a result, the fauna of Xyelidae in Daohugou embraces now two subfamilies, four tribes (Liadoxyelini, Xyeleciini, Gigantoxyelini and Angaridyelini Rasnitsyn, 1966), five genera and seven species, of which one tribe (Xyeleciini), one genus and two species are recorded in Daohugou for the first time (Rasnitsyn \& Zhang 2004; Gao et al. 2009; Wang et al. 2012, 2014; present paper). The record of Xyeleciini is the oldest one, since previously the earliest record of the tribe was in the Late Jurassic of Karatau in Kazakhstan (Rasnitsyn 1969). The new records help little in understanding general features of the biota and environments of Daohugou because Mesozoic Xyelidae show little distinct ecological diversity. As adults they were mostly palynophagous (Krassilov \& Rasnitsyn 1982, 1999; Krassilov et al. 2003, 2007), and the same is known for larvae of most living Xyelinae (Blank et al. 2013, and references therein). Cretaceous and Cenozoic Xyelidae (living included) are known to be temperate insects avoiding hot climates (Rasnitsyn 1969; Rasnitsyn \& Martínez-Delclòs 2000), but this does not necessarily hold true in the Jurassic (cf. Rasnitsyn 1980: 145-147). The only ecological inference possible to draw from the xyelid abundance in Daohugou is that the source territory was well forested, as the pollen found in the gut of Mesozoic Xyelidae is apparently characteristic mainly of trees (cf. above references). This inference is in accord with the presence of various xylophagous 
Symphyta (Anaxyelidae, Siricidae) and parasites of xylophagous insects (Paroryssidae, Ephialtitidae, Praeaulacidae) in Daohugou (Rasnitsyn \& Zhang 2004).

\section{Conclusions}

The description of Platyxyela tenuis sp. nov. and Scleroxyela daohugouensis gen. et sp. nov. enlarges considerably our knowledge of the composition of the xyelid fauna of Daohugou and supports the inference of forested shores of the Daohugou paleolake.

\section{Acknowledgements}

This research is supported by grants from the Scientific Foundation of the National Natural Science Foundation of China (41702012, 41688103), China Postdoctoral Science Foundation funded project (2017M621852), the Strategic Priority Research Program (B) of the Chinese Academy of Sciences (XDB26000000, XDB26010304), Science Foundation of Shandong Province (ZR2018BC012) and Shandong Provincial Key Research and Development Program (2019GNC106135).

\section{References}

Aguiar A.P., Deans A.R., Engel M.S., Forshage M., Huber J.T., Jennings J.T., Johnson N.F., Lelej A.S., Longino J.T., Lohrmann V., Mikó I., Ohl M., Rasmussen C., Taeger A. \& Yu D.S.K. 2013. Order Hymenoptera. Zootaxa 3703 (1): 51-62. https://doi.org/10.11646/zootaxa.3703.1.12

Blank S.M., Shinohara A. \& Altenhofer E. 2013. The Eurasian species of Xyela (Hymenoptera, Xyelidae): taxonomy, host plants and distribution. Zootaxa 3629 (1): 1-106.

https://doi.org/10.11646/zootaxa.3629.1.1

Chen W., Ji Q., Liu D.Y., Zhang Y., Song B. \& Liu X.Y. 2004. Isotope geochronology of the fossilbearing beds in the Daohugou area, Ningcheng, Inner Mongolia. Geological Bulletin of China 23: 11651169. [In Chinese].

Engel M.S. 2005. A new sawfly from the Triassic of Queensland (Hymenoptera: Xyelidae). Memoirs of the Queensland Museum 51 (2): 558.

Gao T.P., Ren D. \& Shih C.K. 2009. Abrotoxyela gen. nov. (Insecta, Hymenoptera, Xyelidae) from the Middle Jurassic of Inner Mongolia, China. Zootaxa 2094 (1): 52-59.

https://doi.org/10.11646/zootaxa.2094.1.6

Huber J.T. \& Sharkey M.J. 1993. Chapter 3. Structure. In: Goulet H. \& Huber J.T. (eds) Hymenoptera of the World: An Identification Guide to Families: 13-59. 239 Research Branch Agriculture Canada, Publication 1894/E. Centre for Land and Biological Resources Research, Ottawa.

Kopylov D.S. 2014. New sawflies of the subfamily Madygellinae (Hymenoptera, Xyelidae) from the Middle-Upper Triassic of Kyrgyzstan. Paleontological Journal 48 (6): 610-620. https://doi.org/10.1134/S0031030114060070

Krassilov V.A. \& Rasnitsyn A.P. 1982. A unique finding: pollen in the intestine of Early Cretaceous sawflies. Paleontological Journal 16 (4): 80-94. [in Russian].

Krassilov V.A. \& Rasnitsyn A.P. 1999. Plant remains from the guts of fossil insects: evolutionary and paleoecological inferences. In: Proceedings of the First Palaeoentomological Conference Moscow 1998. Bratislava, AMBA projects: 65-72. Abstract available from http://palaeoentomolog.ru/Publ/proceedings98.html [accessed 4 Dec. 2020]. 
Krassilov V., Tekleva M., Meyer-Melikyan N. \& Rasnitsyn A.P. 2003. New pollen morphotype from gut compression of a Cretaceous insect, and its bearing on palynomorphological evolution and palaeoecology. Cretaceous Research 24 (2): 149-156. https://doi.org/10.1016/S0195-6671(03)00029-6

Krassilov V.A., Rasnitsyn A.P. \& Afonin S.A. 2007. Pollen eaters and pollen morphology: coevolution through the Permian and Mesozoic. African Invertebrates 47 (1): 3-11. Available from https://hdl.handle.net/10520/EJC84595 [accessed 4 Dec. 2020].

Lara M.B., Rasnitsyn A.P. \& Zavattieri A.M. 2014. Potrerilloxyela menendezi gen. et sp. nov. from the Late Triassic of Argentina: the oldest representative of Xyelidae (Hymenoptera: Symphyta) for Americas. Paleontological Journal 48 (2): 182-190. https://doi.org/10.1134/S0031030114020075

Liu S., Shih C.K. \& Ren D. 2014. Four new species of hangingflies (Insecta, Mecoptera, Bittacidae) from the Middle Jurassic of northeastern China. ZooKeys 466: 77-94.

https://doi.org/10.3897/zookeys.466.8047

Makarkin V., Yang Q., Shih C.K. \& Ren D. 2013. The presence of the recurrent veinlet in the Middle Jurassic Nymphidae (Neuroptera): a unique character condition in Myrmeleontoidea. ZooKeys 325: 1-20. https://doi.org/10.3897/zookeys.325.5453

Rasnitsyn A.P. 1964. New Triassic Hymenoptera from Central Asia. Paleontologicheskii Zhurnal 1964 (1): 88-96. [in Russian].

Rasnitsyn A.P. 1966. New Xyelidae (Hymenoptera) from the Mesozoic of Asia. Paleontologicheskii Zhurnal 1966 (4): 69-85. [in Russian, translated into English in International Geology Review 1967 (9): 723-737].

Rasnitsyn A.P. 1969. Origin and evolution of Lower Hymenoptera. Trudy Paleontologicheskogo Instituta Academii Nauk SSSR 123: 1-196. [in Russian].

Rasnitsyn A.P. 1977. New Hymenoptera from the Jurassic and Cretaceous of Asia. Paleontologicheskii Zhurnal 1977 (3): 98-108. [in Russian].

Rasnitsyn A.P. 1980. Origin and evolution of Hymenoptera. Trudy Paleontologicheskogo Instituta Academii Nauk SSSR 174: 1-192. [in Russian].

Rasnitsyn A.P. 1983. Hymenopterous insects in Jurassic of the Eastern Siberia. Byulleten' Moskovskogo Obshchestva Ispytateley Prirody, Otdel Biologicheskiy 58 (5): 85-94. [in Russian].

Rasnitsyn A.P. \& Martínez-Delclòs X. 2000. Wasps (Insecta: Vespida = Hymenoptera) from the Early Cretaceous of Spain. Acta Geologica Hispanica 35 (1-2): 65-95. Available from http://hdl.handle.net/2445/34667 [accessed 4 Dec. 2020].

Rasnitsyn A.P. \& Zhang H.C. 2004. A new family, Daohugoidae fam. n., of siricomorph hymenopteran (Hymenoptera $=$ Vespida) from the Middle Jurassic of Daohugou in Inner Mongolia (China). Trudy Russkogo Entomologicheskogo Obshchestva 75 (1): 12-16.

Rasnitsyn A.P \& Zhang H.C Z. 2010. Early evolution of Apocrita (Insecta, Hymenoptera) as indicated by new findings in the Middle Jurassic of Daohugou, Northeast China. Acta Geologica Sinica 84 (4): 834-873. https://doi.org/10.1111/j.1755-6724.2010.00254.x

Riek E.F. 1955. Fossil insects from the Triassic beds at Mt. Crosby, Queensland. Australian Journal of Zoology 3 (4): 654-691. https://doi.org/10.1071/ZO9550654

Schlüter T. 2000. Moltenia rieki n. gen., n. sp. (Hymenoptera: Xyelidae?), a tentative sawfly from the Molteno Formation (Upper Triassic), South Africa. Paläontologische Zeitschrift 74 (1-2): 75-78. https://doi.org/10.1007/BF02987953 
Taeger A., Blank S.M. \& Liston A.D. 2010. World catalog of Symphyta (Hymenoptera). Zootaxa 2580: 1-1064. https://doi.org/10.11646/zootaxa.2580.1.1

Wang C., Shih C.K., Rasnitsyn A.P \& Wang M. 2016. Two new species of Prolyda from the Middle Jurassic ofChina(Hymenoptera, Pamphilioidea).ZooKeys 569:71-80. https://doi.org/10.3897/zookeys.569.7249

Wang M., Shih C.K. \& Ren D. 2012. Platyxyela gen. nov. (Hymenoptera, Xyelidae, Macroxyelinae) from the Middle Jurassic of China. Zootaxa 3456 (1): 82-588. https://doi.org/10.11646/zootaxa.3456.1.4

Wang M., Rasnitsyn A.P. \& Ren D. 2014. Two new fossil sawflies (Hymenoptera, Xyelidae, Xyelinae) from the Middle Jurassic of China. Acta Geologica Sinica (English Edition) 88 (4): 1027-1033. https://doi.org/10.1111/1755-6724.12269

Zhang H.C. \& Zhang J.F. 2000. Xyelid sawflies (Insecta, Hymenoptera) from the Upper Jurassic Yixian formation of western Liaoning, China. Acta Palaeontologica Sinica 39 (4): 476-492. https://doi.org/10.3969/j.issn.0001-6616.2000.04.003

Zhang J.F. 2012. Orientisargidae fam. n., a new Jurassic family of Archisargoidea (Diptera, Brachycera), with review of Archisargidae from China. ZooKeys 238: 57-76.

https://doi.org/10.3897/zookeys.238.3624

Zheng Y. \& Chen J. 2017. A new mesoserphid wasp from the Middle Jurassic of northeastern China (Hymenoptera, Proctotrupoidea). European Journal of Taxonomy 379: 1-8.

https://doi.org/10.5852/ejt.2017.379

Zheng Y., Chen J. \& Wang X.L. 2016. A new genus and species of Tettigarctidae from the Mesozoic of northeastern China (Insecta, Hemiptera, Cicadoidea). ZooKeys 632: 47-55. https://doi.org/10.3897/zookeys.632.10076

Zheng Y., Chen J., Zhang J.Q. \& Zhang H.C. 2019. New fossil sawflies (Hymenoptera, Xyelidae) from the Middle Jurassic of northeastern China. Alcheringa: An Australasian Journal of Palaeontology 44: 115-120. https://doi.org/10.1080/03115518.2019.1641618

Manuscript received: 21 September 2020

Manuscript accepted: 5 October 2020

Published on: 9 February 2021

Topic editor: Christian de Muizon

Desk editor: Natacha Beau

Printed versions of all papers are also deposited in the libraries of the institutes that are members of the EJT consortium: Muséum national d'histoire naturelle, Paris, France; Meise Botanic Garden, Belgium; Royal Museum for Central Africa, Tervuren, Belgium; Royal Belgian Institute of Natural Sciences, Brussels, Belgium; Natural History Museum of Denmark, Copenhagen, Denmark; Naturalis Biodiversity Center, Leiden, the Netherlands; Museo Nacional de Ciencias Naturales-CSIC, Madrid, Spain; Real Jardín Botánico de Madrid CSIC, Spain; Zoological Research Museum Alexander Koenig, Bonn, Germany; National Museum, Prague, Czech Republic. 